\title{
Chromium(VI) adsorption from aqueous solution by prepared biochar from Onopordom Heteracanthom
}

\author{
S. Ghorbani-Khosrowshahi ${ }^{1} \cdot$ M. A. Behnajady ${ }^{1}$
}

Received: 3 July 2015/Revised: 27 November 2015/Accepted: 8 March 2016/Published online: 4 April 2016

(C) Islamic Azad University (IAU) 2016

\begin{abstract}
In this research, the stems of Onopordom Heteracanthom which is a kind of weed were converted to biochar particles, and their characteristics were investigated. The morphology and purity of these particles were examined by SEM and EDX techniques, respectively. Specific surface area was obtained as $5.73 \mathrm{~m}^{2} \mathrm{~g}^{-1}$ by BET method. The biochar particles obtained from Onopordom Heteracanthom were evaluated as an adsorbent to remove $\mathrm{Cr}(\mathrm{VI})$ from aqueous environments. The effect of some parameters such as initial concentration of $\mathrm{Cr}(\mathrm{VI})$, dosage of adsorbent, and $\mathrm{pH}$ were investigated on the adsorption capacity of $\mathrm{Cr}(\mathrm{VI})$ onto the adsorbent. The equilibrium data were analyzed by various isotherm models. The results revealed that in this process, the adsorption isotherm and kinetics have more conformity with Langmuir isotherm and pseudo-second-order kinetics, respectively. The multilinearity of the Weber and Morris adsorption kinetic model indicates that the intra-particle diffusion is not merely the rate-controlling step for the whole adsorption process.
\end{abstract}

Keywords Adsorption $\cdot$ Biochar $\cdot \mathrm{Cr}(\mathrm{VI}) \cdot$ Onopordom Heteracanthom

\section{Introduction}

All over the world, the pollution of water resources has increased due to the disposal of heavy metals. Removing heavy metals from water and wastewaters as a result of

M. A. Behnajady

behnajady@gmail.com

1 Department of Chemistry, Tabriz Branch, Islamic Azad University, Tabriz, Iran industrialization has turned out to be a serious problem. Discharging of metals into water resources is one of the most critical issues regarding pollution which may have negative effects on the quality of water supply. Increasing concentrations of heavy metals in water resources have negative effects on the quality of water and have caused severe threats to the health of humankind, which are mainly related to their non-degradability and toxicity (Gode et al. 2008).

There are different heavy metals such as $\mathrm{Cd}, \mathrm{Cu}, \mathrm{Zn}, \mathrm{Ni}$, and $\mathrm{Cr}(\mathrm{VI})$ in surface waters (Behnajady and Bimeghdar 2014; Hu et al. 2005). Chromium has a broad usage in industry due to its strong crystalline structure, corrosion resistance, and yellow color. It is one of the essential materials in electroplating industries, tanneries, paint and pigments, wood preservation, and alloy making processes (Gupta and Babu 2009).

The toxicity of hexavalent chromium is 500 times more than the trivalent form due to its carcinogenic and mutagenic effects. Human toxicity of $\mathrm{Cr}(\mathrm{VI})$ includes skin irritation to lung cancer, as well as kidney, liver, and gastric damage (Das and Vinodhini 2010; Kotas and Stasicka 2000).

Several treatment techniques have been used for the removal of $\mathrm{Cr}(\mathrm{VI})$ from wastewater; this includes techniques such as membrane separation (Bhowal et al. 2012), electrocoagulation (Zongo et al. 2009), solvent extraction (Venkateswaran and Palanivelu 2004), reduction (An et al. 2014), reverse osmosis (Chun et al. 2004), adsorption (Behnajady and Bimeghdar 2014), and photoreduction (Behnajady et al. 2012).

However, most of these methods not only are expensive but also have many disadvantages such as incomplete metal removal, high reagent, and energy requirements (Aliabadi et al. 2006; Gupta and Babu 2009). In order to 
achieve complete removal of the metals, adsorption can be remarked as a proper procedure with low usage of chemicals and energy. It can be a suitable and effective low-cost method for separating heavy metals from aqueous phase if a low-cost and effective adsorbent has been used (Bailey et al. 1999).

Despite of the fact that adsorption by activated carbon is a major technique for removing toxic pollutants from wastewaters, it is too expensive to be used practically. Therefore, there is a need to develop a low-cost adsorbent for the removal of heavy metal ions from the aqueous environment. Several types of biomasses have been explored as the alternate cases in wastewater treatment for chromium removal. The different biomasses which were tested in previous studies include corncob waste (MorenoPirajana et al. 2013), saw dust (Mane and Vijay-Babu 2011), coconut shell carbon (Amuda et al. 2007), tea waste (Malkoc and Nuhoglu 2006), rice hulls (Marshall and Wartelle 2004), hazelnut shell (Ayoama et al. 1999) etc.

The aim of this study is to investigate the possibility for the preparation of biochar from a weed (Onopordom Heteracanthom), as an alternate low-cost adsorbent material for the removal of $\mathrm{Cr}(\mathrm{VI})$ from wastewater. The impact of the initial concentration of $\mathrm{Cr}(\mathrm{VI})$, adsorbent dosage, and initial $\mathrm{pH}$ on the adsorption capacity were investigated. Furthermore, the adsorption isotherms and kinetics were deduced from the experimental results. This research has been conducted between December 23 and September 11 of 2013 in the laboratory of applied chemistry of Islamic Azad University, Tabriz Branch.

\section{Materials and methods}

\section{Preparation of adsorbent}

Onopordom Heteracanthom $(\mathrm{OH})$ was obtained from the suburbs of Tabriz, Iran. $O H$ is a thorn with approximately $80-120 \mathrm{~cm}$ of height and is among many herbs which grow beside roads and cultivated or undeveloped farms. Its seeds are used in medicinal industry, but its bough is not useful and is considered as agricultural products waste. The geographical dispersion of this plant covers all areas of Iran. Firstly, the samples were cleaned from thorns and leaves and were divided into smaller particles. The particles were milled and then were washed with deionized water until all leachable impurities were removed. Finally, the samples were dried in hot air oven at $100{ }^{\circ} \mathrm{C}$ for $4 \mathrm{~h}$. Thereafter, the samples were treated with $\mathrm{H}_{2} \mathrm{SO}_{4}(50 \%)$ at the ratio of 2:1 (acid volume/weight of $\mathrm{OH}$ ), and they were allowed to get carbonized at $150{ }^{\circ} \mathrm{C}$ in hot air oven for $24 \mathrm{~h}$ and soaked with deionized water until the $\mathrm{pH}$ of solution got stable. Afterward, the produced carbon was soaked in $2 \% \mathrm{NaHCO}_{3}(\mathrm{w} / \mathrm{v})$ till any residual acid was removed. Finally, the samples were dried in hot air oven at $110{ }^{\circ} \mathrm{C}$, cooled, sieved in the size of $300 \mu \mathrm{m}$, and stored for further utilization (Kadirvelu et al. 2001). Zero point charge (ZPC) of adsorbent determined by salt addition method (Mahmood et al. 2011).

\section{Characterization methods}

The prepared adsorbent was characterized using different techniques such as Brunauer-Emmett-Teller (BET), scanning electron microscopy (SEM), Fourier transform infrared spectroscopy (FT-IR), and energy-dispersive X-ray (EDX).

\section{Adsorption experiments}

$\mathrm{Cr}(\mathrm{VI})$ solution was prepared using analytical grade of $\mathrm{K}_{2} \mathrm{Cr}_{2} \mathrm{O}_{7}$ obtained from Merck Company and stored at room temperature. This stock solution was used to prepare dilute solutions of chromium ion by the dilution with double distilled water. The adsorption studies of $\mathrm{Cr}(\mathrm{VI})$ ions onto the adsorbent were investigated in a shaking water bath with a constant speed of $140 \mathrm{rpm}$. In each experiment a certain amount of adsorbent was mixed with $100 \mathrm{~mL}$ of $\mathrm{Cr}(\mathrm{VI})$ solution at a given initial concentration and $\mathrm{pH}$ in a fixed temperature. After mixing them, every $10 \mathrm{~min}$, about $5 \mathrm{~mL}$ of the solution was sampled and separated from the adsorbent using filter paper. The residual amount of $\mathrm{Cr}(\mathrm{VI})$ ions in the samples was determined using UV/Vis spectrophotometer (Shimadzu, UV1700 ) in the maximum wavelength of $\mathrm{Cr}(\mathrm{VI})$ (Mohapatra et al. 2005).

The effect of the initial concentration of $\mathrm{Cr}(\mathrm{VI})(10,20$, $\left.30,40,50,60 \mathrm{mg} \mathrm{L}^{-1}\right)$, dosage of adsorbent $(0.1,0.15$, $0.2 \mathrm{~g})$, and initial $\mathrm{pH}(1,2,3,4)$ were investigated in this research. The adsorption yield $(R \%)$ and the amount of the adsorbed per unit of adsorbent $\left(q_{\mathrm{e}}\right)$ were calculated by Eqs. 1 and 2, respectively:

$R \%=\frac{\left(C_{0}-C_{t}\right)}{C_{0}} \times 100$

$q_{e}=\frac{\left(C_{0}-C_{e}\right) \times V}{W}$

where $C_{0}$ is the initial concentration of $\mathrm{Cr}(\mathrm{VI})\left(\mathrm{mg} \mathrm{L}^{-1}\right), C_{t}$ is the concentration of $\mathrm{Cr}(\mathrm{VI})$ at any time $\left(\mathrm{mg} \mathrm{L}^{-1}\right), C_{e}$ is the equilibrium concentration of $\mathrm{Cr}(\mathrm{VI})\left(\mathrm{mg} \mathrm{L}^{-1}\right), V$ is the volume of $\mathrm{Cr}(\mathrm{VI})$ solution (L) and $W$ is the weight of the adsorbent (g). 


\section{Results and discussion}

\section{Characterization of adsorbent}

Fourier transform infrared (FT-IR) was used to determine the changes of vibration frequency in the functional groups of the adsorbent due to $\mathrm{Cr}(\mathrm{VI})$ adsorption. The FT-IR spectrum within $500-4000 \mathrm{~cm}^{-1}$ for the biochar particles obtained from the $\mathrm{OH}(\mathrm{BCP})$ before and after the adsorption of $\mathrm{Cr}(\mathrm{VI})$ is shown in Fig. 1a, b.

In the case of BCP (Fig. 1a), the peak point of around $3413.17 \mathrm{~cm}^{-1}$ indicates the existence of free and intermolecular bonded hydroxyl groups. Also the peak position of $1622 \mathrm{~cm}^{-1}$ in the FT-IR spectrum of BCP can be related to the $\mathrm{C}=\mathrm{C}$ bond. The additional peak at $618 \mathrm{~cm}^{-1}$ can be attributed to bending modes of aromatic compounds.

The FT-IR spectrum of Cr(VI) loaded BCP (Fig. 1b) indicates that there is remarkable change in the hydroxyl group peak at $3413.17 \mathrm{~cm}^{-1}$ which it can be due to $\mathrm{Cr}(\mathrm{VI})$ binding mostly with hydroxyl groups (Garg et al. 2007).

For determining the specific surface area, total pore volume, and pore size of BCP, BET-BJH methods were used. According to the BET method, the specific surface area and mean pore diameter was obtained as $5.73 \mathrm{~m}^{2} \mathrm{~g}^{-1}$ and $4.5 \mathrm{~nm}$, respectively. The nitrogen adsorption-desorption isotherm onto BCP is shown in Fig. 2a, which is in correspondence with classical Type III isotherm of IUPAC classification and indicates weak adsorbent-adsorbate interactions on non-porous or macroporous adsorbent (Rouquerol et al. 2013). BCP pore size distribution was determined by the BJH method. Figure $2 b$ shows a board distribution (1-50 nm) for pore size distribution.

SEM images have been used for morphological study of BCP. The SEM micrographs of BCP before and after adsorption of $\mathrm{Cr}(\mathrm{VI})$ are shown in Fig. 3a, b, respectively. In the SEM image of BCP, the porous structure is obvious, but in the case of the used particles, the pores have been covered by the adsorbate.

The EDX spectrum of BCP before and after adsorption of $\mathrm{Cr}(\mathrm{VI})$ was evaluated. The spectrum clearly indicates the peak of element $\mathrm{C}$. There is a remarkable reduction in the intensity of peak of $\mathrm{C}$ in the used sample (Fig. 3c), comparing with the fresh one, and also the peak of $\mathrm{Cr}(\mathrm{VI})$ is notable on the used BCP.
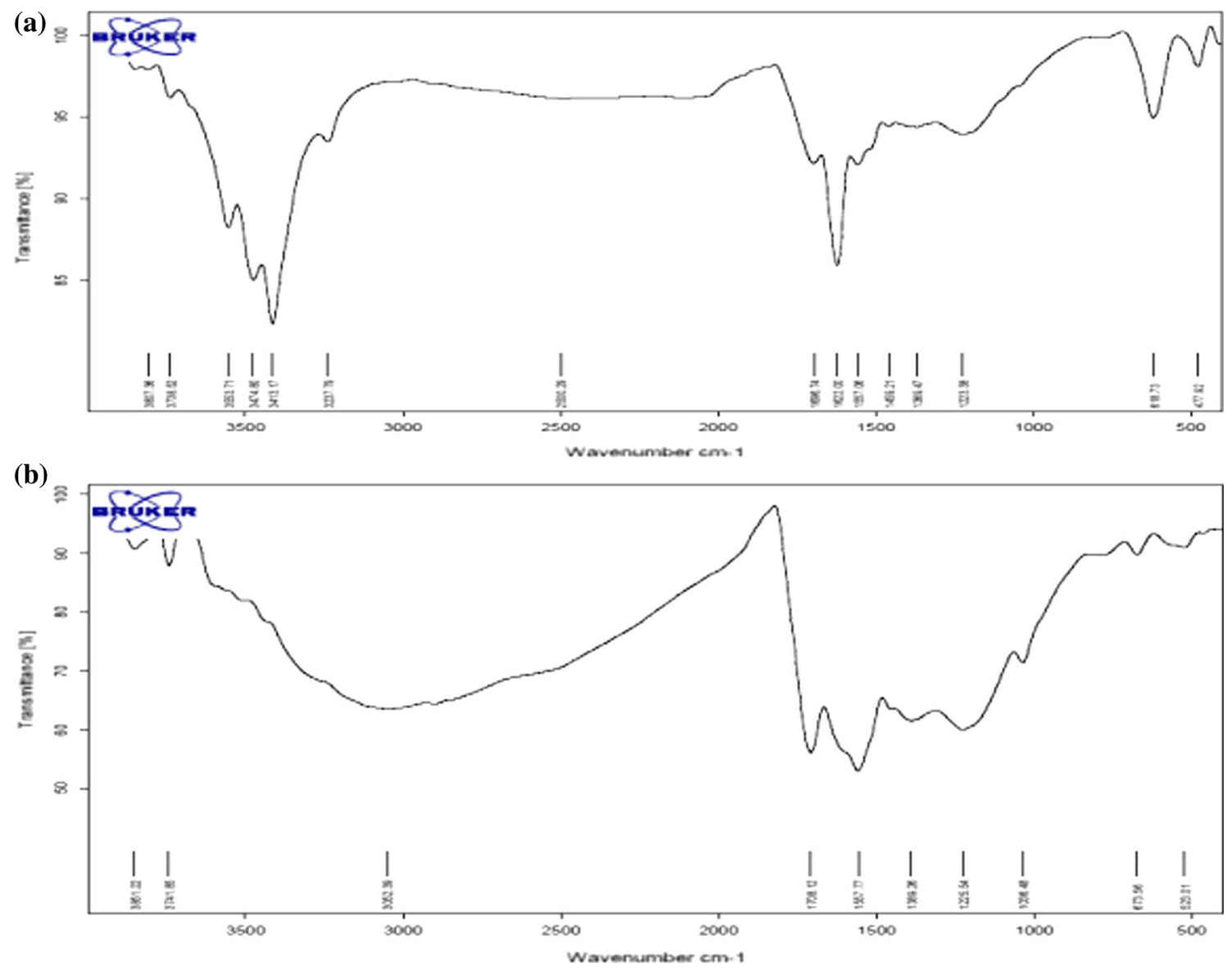

Fig. 1 FT-IR spectrum of BCP before (a) and after adsorption of $\mathrm{Cr}(\mathrm{VI})(\mathbf{b})$ 


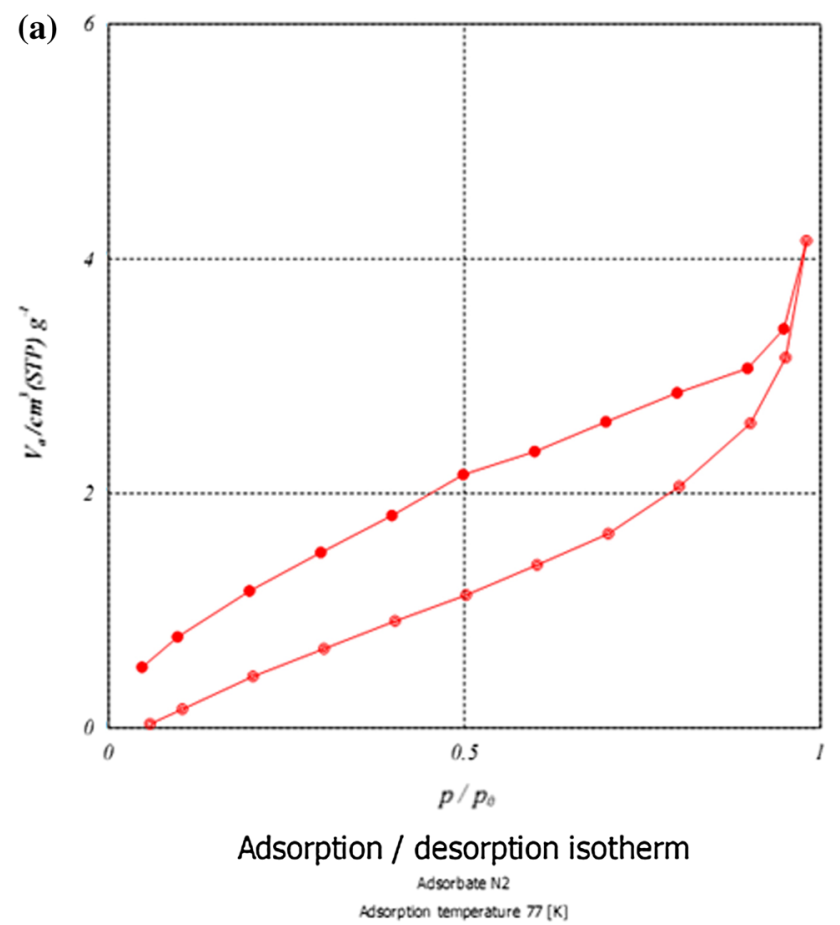

(b)

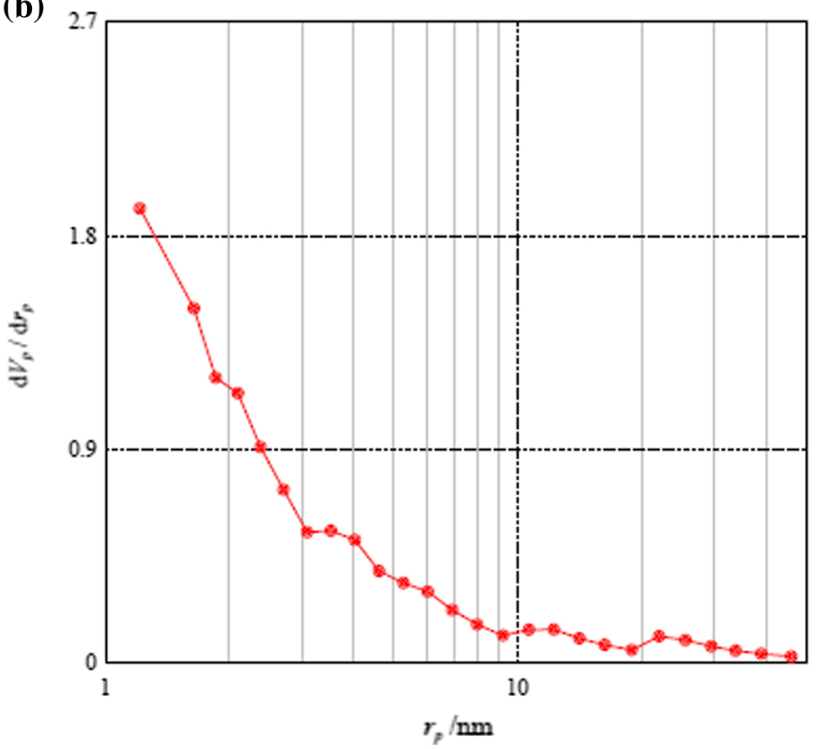

Fig. 2 Nitrogen adsorption-desorption isotherm (a) and BJH pore size distribution of BCP (b)

\section{Adsorption studies}

\section{The effect of the initial concentration of $\mathrm{Cr}(\mathrm{VI})$}

One of the most important parameters that influence adsorption process is the initial concentration of adsorbate. Therefore, the effect of the initial concentration of $\mathrm{Cr}(\mathrm{VI})$ was studied by performing the experiments at different initial concentrations $\left(10,20,30,40,50\right.$ and $\left.60 \mathrm{mg} \mathrm{L}^{-1}\right)$ keeping $\mathrm{pH}(2.0)$, adsorbent dose $(0.1 \mathrm{~g})$, stirring speed (140 rpm), and temperature $\left(15 \pm 1{ }^{\circ} \mathrm{C}\right)$ constant. The results of this study are shown in Fig. 4a. This diagram indicated that the percentage of adsorption decreased by increasing the initial concentration of $\mathrm{Cr}(\mathrm{VI})$; it is apparent that the adsorbent had a limited number of active sites, and these sites were saturated in a certain concentration, so the saturated adsorbent would not be able to uptake more $\mathrm{Cr}$ (VI) molecules (Chowdhury et al. 2011).

The results in Fig. $4 \mathrm{~b}$ indicate that the capacity of adsorbent increased by increasing the initial concentration of $\mathrm{Cr}(\mathrm{VI})$. The increase in concentration can provide a driving force to overcome all-mass transfer resistances from aqueous to solid phase (Chowdhury et al. 2011).

\section{The effect of $B C P$ dosage}

The effect of BCP dosage on the adsorption of $\mathrm{Cr}(\mathrm{VI})$ from aqueous solutions was evaluated. Figure 5 a shows the effect of BCP dosage on the adsorption capability of $\mathrm{Cr}(\mathrm{VI})$. Increasing the adsorption efficiency by increasing adsorbent dosage was due to the availability of greater surface area and adsorption sites for the constant number of $\mathrm{Cr}(\mathrm{VI})$ ions (Rasoulifard et al. 2010).

Figure $5 \mathrm{~b}$ indicates that by increasing the adsorbent dosage from 0.1 to $0.2 \mathrm{~g}$, the value of $q_{\mathrm{eq}}$ also decreases. This reduction may be attributed to unsaturation of adsorption sites and also increase in diffusionpath length resulting from aggregation of BCP particles (Behnajady and Bimeghdar 2014).

\section{The effect of initial $\mathrm{pH}$}

The effect of $\mathrm{pH}$ on the adsorption of $\mathrm{Cr}(\mathrm{VI})$ from aqueous environments onto $\mathrm{BCP}$ has been investigated. This parameter influences both the chemical state of $\mathrm{Cr}(\mathrm{VI})$ and the surface charge of adsorbent. The adsorption percentage of $\mathrm{Cr}(\mathrm{VI})$ onto $\mathrm{BCP}$ as a function of $\mathrm{pH}$ was studied. By increasing $\mathrm{pH}$, the percentage of $\mathrm{Cr}(\mathrm{VI})$ adsorption decreases. The adsorption percentage of $\mathrm{Cr}(\mathrm{VI})$ onto $\mathrm{BCP}$ was $88,69,6$ and $0.5 \%$ for the $\mathrm{pH}$ values of $1,2,3$ and 4 , respectively. The $\mathrm{pH}$ of zero point charge for adsorbent (pHzpc) is 2 and as we know the surface charge is neutral at $\mathrm{pHzpc}$. For lower $\mathrm{pH}$ values ( $\mathrm{pH}$ below $\mathrm{pHzpc}$ ), the surface of adsorbent is covered by $\mathrm{H}^{+}$ions and has a positive electrical load, while at higher ones the adsorbent surface involves negative electrical load. Consequently, at lower $\mathrm{pH}$ values it is easier for dichromate ion to load onto adsorbent (Gupta and Babu 2009). 

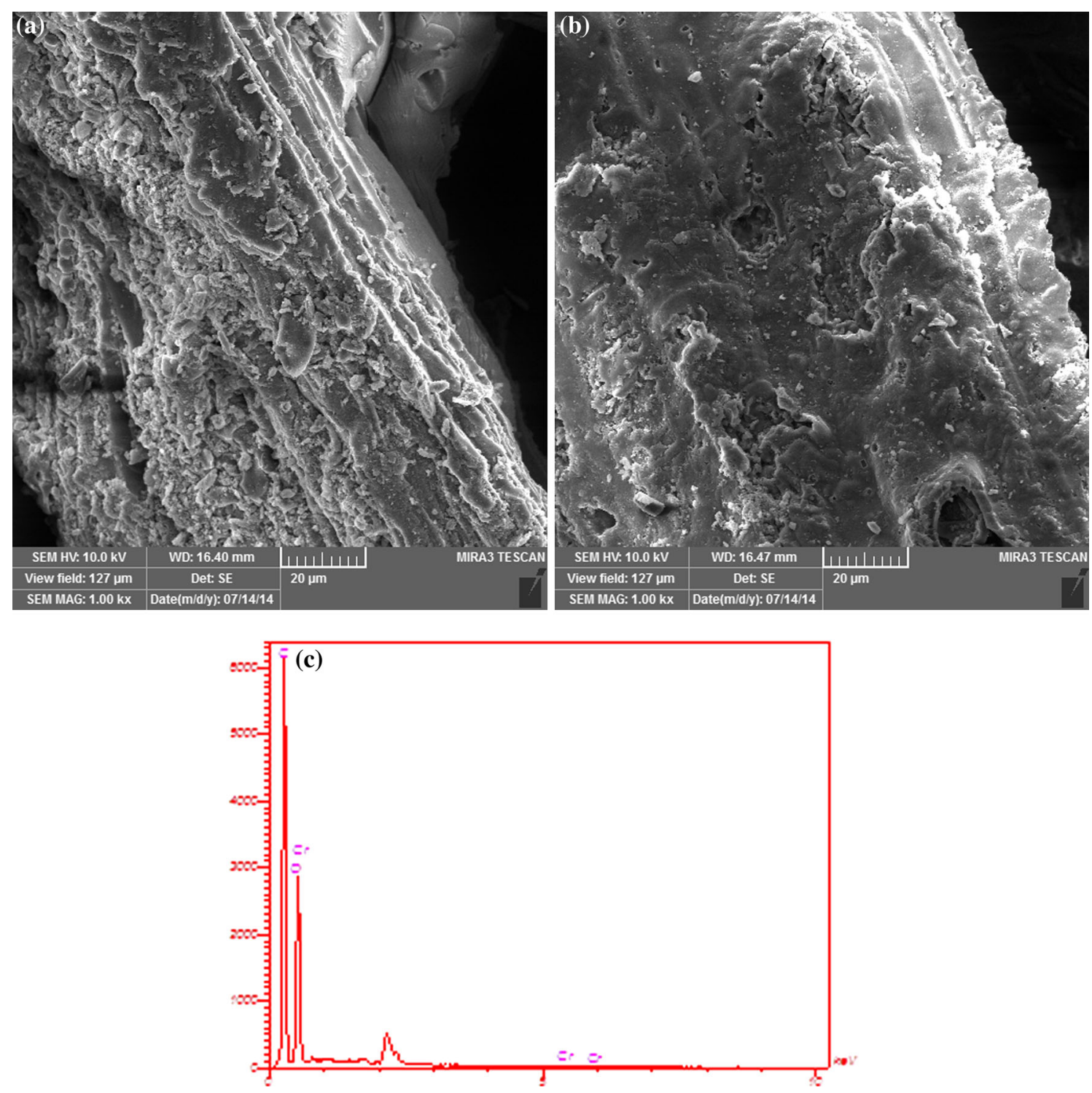

Fig. 3 The SEM image of BCP before (a) and after adsorption of $\mathrm{Cr}(\mathrm{VI})(\mathbf{b})$, EDX spectrum of BCP after adsorption of $\mathrm{Cr}(\mathrm{VI})$ (c)

\section{Equilibrium isotherm studies}

The adsorption isotherm explains the way of interactions between adsorbent and adsorbate. Therefore, it is always considered as a major factor for determining the adsorbent capacity and optimizing adsorbent consumption. In this condition, the distribution of solute between solution and adsorbent surface is expressed as a function of $C_{\mathrm{e}}$ and $q_{\mathrm{e}}$ at a constant temperature called equilibrium adsorption isotherm (Kundu and Gupta 2006).

Several 2 and 3-parameters isotherm models have been used in this study. The isotherm parameters were evaluated by nonlinear trial and error method using
Polymath 6.0 software. As the higher values of correlation coefficient $\left(R^{2}\right)$ and adjusted correlation coefficient $\left(R_{\text {adj }}^{2}\right)$, it can be concluded that the data are in a better agreement with the mentioned model. The average values of observations $(\bar{y}), R^{2}$ and $R_{\text {adj }}^{2}$ were calculated by Eqs. 3-5, respectively:

$\bar{y}=\frac{1}{n}\left(\sum_{i=1}^{n} y_{i_{\text {obs. }}}\right)$

$R^{2}=1-\frac{\sum_{i=1}^{n}\left(y_{\mathrm{iobss}_{\mathrm{s}}}-y_{i_{\text {calc. }}}\right)^{2}}{\sum_{i=1}^{n}\left(y_{i_{\mathrm{obs} .}}-\bar{y}\right)^{2}}$ 

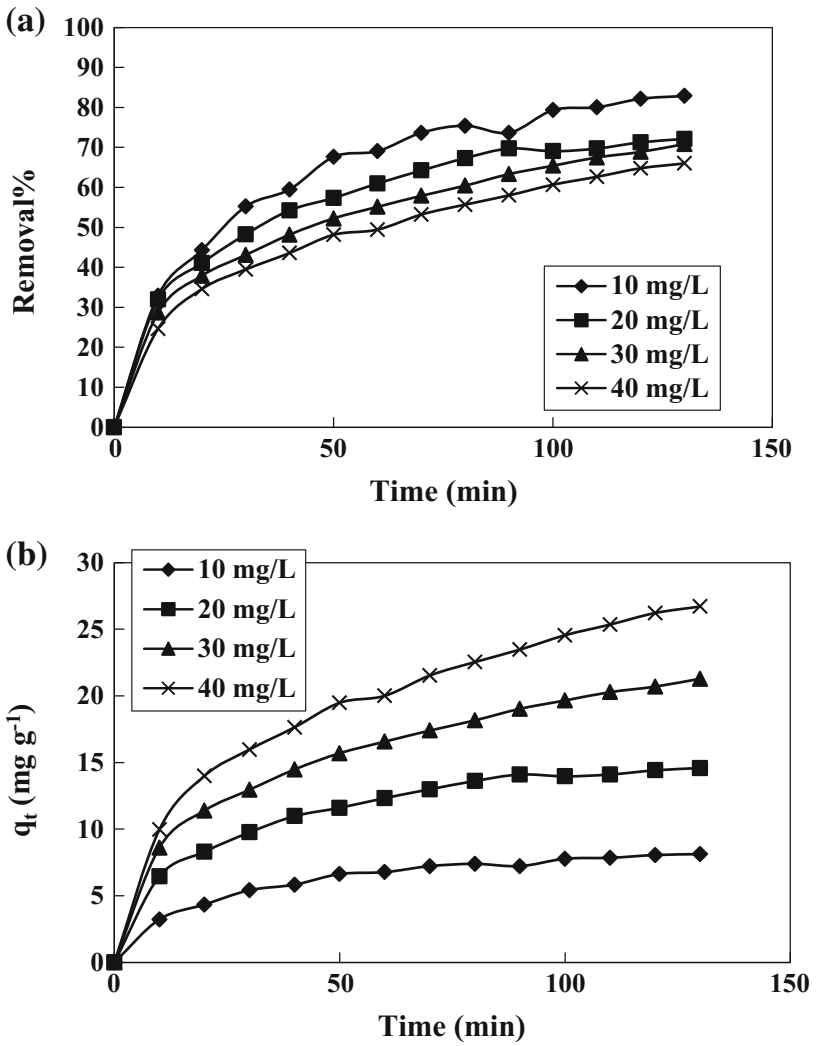

Fig. 4 Effect of initial $\mathrm{Cr}(\mathrm{VI})$ concentration on the adsorption percent of $\mathrm{Cr}(\mathrm{VI})$ onto $\mathrm{BCP}(\mathbf{a})$ and $\mathrm{q}_{\mathrm{eq}}(\mathbf{b})(\mathrm{BCP}=0.1 \mathrm{~g}, \mathrm{pH}=2$, $T=15 \pm 1{ }^{\circ} \mathrm{C}$

$R_{\text {adj. }}^{2}=1-\frac{\left(1-R^{2}\right)(n-1)}{n-p}$

where $n$ is the number of observations, $y_{i}$ is a specific observation, the notation "obs." relates to the observed data and notation "calc." relates to the calculated data. For comparing the various isotherm models in adsorption of $\mathrm{Cr}(\mathrm{VI})$ by BCP, we have also used variance $\left(S^{2}\right)$ and rootmean-square error (Rmse) parameters. A model with smaller variance and Rmse shows the data accurately. To calculate the values of Rmse and $S^{2}$, Eqs. 6 and 7 have been used, respectively.

Rmse $=\frac{1}{n}\left(\sum_{i=1}^{n}\left(y_{i_{\text {obs. }}}-y_{i_{\text {calc. }}}\right)^{2}\right)^{2}$

$S^{2}=\frac{\sum_{i=1}^{n}\left(y_{i}-\bar{y}\right)^{2}}{n-1}$

The parameters of each model at $95 \%$ confidence interval, $R^{2}, R_{\text {adj. }}^{2}, S^{2}$ and Rmse were calculated and are given in Table 1. For the regression model to be stable and statistically valid, the confidence intervals must be much
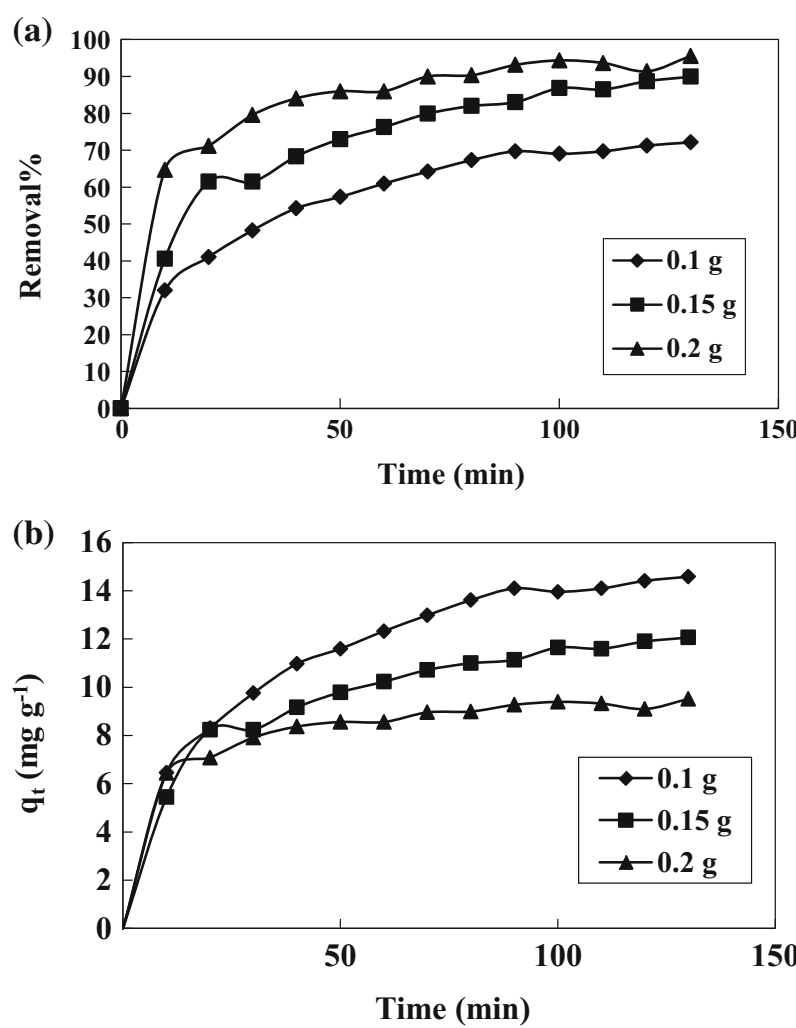

Fig. 5 Effect of initial dosage of BCP on the adsorption percent of $\mathrm{Cr}(\mathrm{VI})$ onto $\mathrm{BCP}$ (a) and $\mathrm{q}_{\mathrm{eq}}$ (b) $\left([\mathrm{Cr}]_{0}=20 \mathrm{mg} \mathrm{L}^{-1}, \mathrm{pH}=2\right.$, $\left.T=15 \pm 1{ }^{\circ} \mathrm{C}\right)$

smaller (or at least smaller) than the respective parameter values (in absolute values). The curves of experimental data and the results obtained from different 2 and 3 parameters models are shown in Fig. 6a, b, respectively.

\section{Langmuir isotherm}

Langmuir model is the most practical and known type of adsorbent isotherm which is in a good agreement with a wide range of experimental data. In the lower concentrations, this equation is converted to the Henry's model (Ho et al. 2001).

The assumptions of Langmuir isotherm can be considered as single layer of adsorption, adsorption in the homogenous sites, homogenous structure of the adsorbent and limited capacity for the adsorption. This isotherm model can be expressed using the following equation:

$q_{e}=\frac{q_{m} K_{L} C_{e}}{1+K_{L} C_{e}}$

where $C_{\mathrm{e}}$ is the equilibrium concentration of solute (mg $\left.\mathrm{L}^{-1}\right), q_{e}$ is the amount of adsorbate adsorbed at equilibrium 
Table 1 Isotherm and kinetics models parameters values ( $\pm 95 \%$ confidence level)

\begin{tabular}{|c|c|c|c|c|c|c|}
\hline Model & $\mathrm{R}^{2}$ & $R_{\text {adj }}^{2}$ & $\mathrm{~S}^{2}$ & Rmse & Parameters & Parameter values \\
\hline \multicolumn{7}{|l|}{ Two- and three- parameter isotherm models } \\
\hline 2-p Langmuir & 0.9795497 & 0.9754597 & 2.962681 & 0.5498312 & $\mathrm{q}_{\mathrm{m}}, \mathrm{K}_{\mathrm{L}}$ & $\begin{array}{r}37.28( \pm 8.17) \\
0.13( \pm 0.08)\end{array}$ \\
\hline 2-p Freundlich & 0.9690305 & 0.9628367 & 4.48662 & 0.9766227 & $\mathrm{~K}_{\mathrm{F}}, \mathrm{n}$ & $\begin{array}{c}7.52( \pm 1.0002) \\
2.38( \pm 6.26)\end{array}$ \\
\hline 2-p Temkin & 0.976497 & 0.9717964 & 3.404935 & 0.5894424 & $\begin{array}{l}\mathrm{q}_{\mathrm{m}} \\
\mathrm{RT} /\left(-\Delta \mathrm{H}^{0}{ }_{\mathrm{ad}}\right) \\
\mathrm{K}_{\mathrm{T}}\end{array}$ & $\begin{array}{l}15.80( \pm 0.0005) \\
0.50( \pm 0.0001) \\
1.42( \pm 0.0001)\end{array}$ \\
\hline 3-p Redlich-Peterson & 0.9797579 & 0.9696369 & 3.66565 & 0.5470254 & $\begin{array}{l}\text { A } \\
\text { B } \\
\text { g }\end{array}$ & $\begin{array}{l}5.42( \pm 2.56) \\
0.18( \pm 0.19) \\
0.93( \pm 0.22)\end{array}$ \\
\hline 3-p Sips & 0.9801056 & 0.9701584 & 3.602684 & 0.5423068 & $\begin{array}{l}\mathrm{q}_{\mathrm{m}} \\
\mathrm{K}_{\mathrm{a}} \\
\alpha\end{array}$ & $\begin{array}{l}40.54( \pm 35.61) \\
0.10( \pm 0.23) \\
0.10( \pm 0.23)\end{array}$ \\
\hline 3-p Toth & 0.9797579 & 0.9696369 & 3.66565 & 0.5470254 & $\begin{array}{l}\mathrm{q}_{\mathrm{m}} \\
\mathrm{K}_{\mathrm{Th}} \\
\beta\end{array}$ & $\begin{array}{l}35.29( \pm 0.001) \\
0.16( \pm 1.43) \\
0.93( \pm 5.74)\end{array}$ \\
\hline \multicolumn{7}{|l|}{ Kinetics models } \\
\hline Pseudo-first- order $\left([\mathrm{Cr}]_{0}=20 \mathrm{mg} \mathrm{L}^{-1}\right)$ & 0.977656 & 0.975794 & 0.4004096 & 0.1565723 & $\begin{array}{l}\mathrm{q}_{\mathrm{e}} \\
\mathrm{k}_{1}\end{array}$ & $\begin{array}{l}14.11( \pm 0.62) \\
0.04( \pm 0.007)\end{array}$ \\
\hline Pseudo-second- order $\left([\mathrm{Cr}]_{0}=20 \mathrm{mg} \mathrm{L}^{-1}\right)$ & 0.9940189 & 0.9935205 & 0.1071818 & 0.0810071 & $\begin{array}{l}\mathrm{q}_{\mathrm{e}} \\
\mathrm{k}_{2}\end{array}$ & $\begin{array}{l}16.65( \pm 0.17) \\
0.003( \pm 0.0001)\end{array}$ \\
\hline Pseudo-first- order $\left([\mathrm{Cr}]_{0}=40 \mathrm{mg} \mathrm{L}^{-1}\right)$ & 0.9649254 & 0.9620025 & 2.04934 & 0.3542172 & $\begin{array}{l}\mathrm{q}_{\mathrm{e}} \\
\mathrm{k}_{1}\end{array}$ & $\begin{array}{l}25.42( \pm 0.0003) \\
0.032( \pm 1.4 \mathrm{E}-06)\end{array}$ \\
\hline $\begin{array}{l}\text { Pseudo-second- order } \\
\left([\mathrm{Cr}]_{0}=40 \mathrm{mg} \mathrm{L}^{-1}\right)\end{array}$ & 0.9862294 & 0.9850819 & 0.8045881 & 0.2219471 & $\begin{array}{l}\mathrm{q}_{\mathrm{e}} \\
\mathrm{k}_{2}\end{array}$ & $\begin{array}{l}31.0846( \pm 0.19) \\
0.001( \pm 3.06 \mathrm{E}-05)\end{array}$ \\
\hline
\end{tabular}

$\left(\mathrm{mg} \mathrm{g}^{-1}\right), q_{m}$ is the maximum adsorption capacity and $K_{\mathrm{L}}$ is the Langmuir adsorption model constant $\left(\mathrm{L} \mathrm{mg}^{-1}\right)$. The obtained $R^{2}$ value for this model $\left(R^{2}=0.979\right)$ indicates that adsorption of $\mathrm{Cr}(\mathrm{VI})$ from aqueous solutions by BCP is based on this model. The maximum adsorption capacity $\left(q_{\mathrm{m}}\right)$ obtained from Langmuir isotherm is $37.28 \mathrm{mg} \mathrm{g}^{-1}$. Table 2 lists maximum capacity of the mono-layer adsorption of BCP and other adsorbents reported in the literature. In general prepared adsorbent in this work exhibited satisfactory adsorption capacity in comparison with other similar adsorbents.

Considering the separation factor for different initial $\mathrm{Cr}$ (VI) concentrations, it can be asserted that in all initial concentrations, the adsorption of $\mathrm{Cr}(\mathrm{VI})$ is favorable.

\section{Freundlich isotherm}

The Freundlich isotherm equation is an empirical equation and is used for studying experimental data in liquid phase. This isotherm is used for describing the multilayer adsorption with the reaction among the adsorbed molecules and also is effective for adsorption on the heterogeneous surfaces (Gimbert et al. 2008; Oubagaranadin and Murthy 2009). This isotherm is an exponential equation with the assumption that by increasing the concentration of the adsorbed mass, there is more amount of adsorption. From theoretical point of view, using this equation can result in unlimited amount of adsorption (Allen et al. 2004). The Freundlich equation can be expressed as follows:

$q_{e}=K_{F} C_{e}^{\frac{1}{n}}$

where $K_{F}$ is Freundlich adsorption model constant $\left(\mathrm{L} \mathrm{g}^{-1}\right)$ and shows the quantity of adsorbate adsorbed onto the adsorbent for a unit equilibrium concentration, and $n$ is Freundlich adsorption model exponent. When the $1 / n$ is equal to 1 , the adsorption is linear. For the values less than 1 , the adsorption process is chemical, and if it is more than one, the adsorption will be a physical process. The most surface heterogeneity occurs when the value of $1 / \mathrm{n}$ is near to zero (Gimbert et al. 2008). 

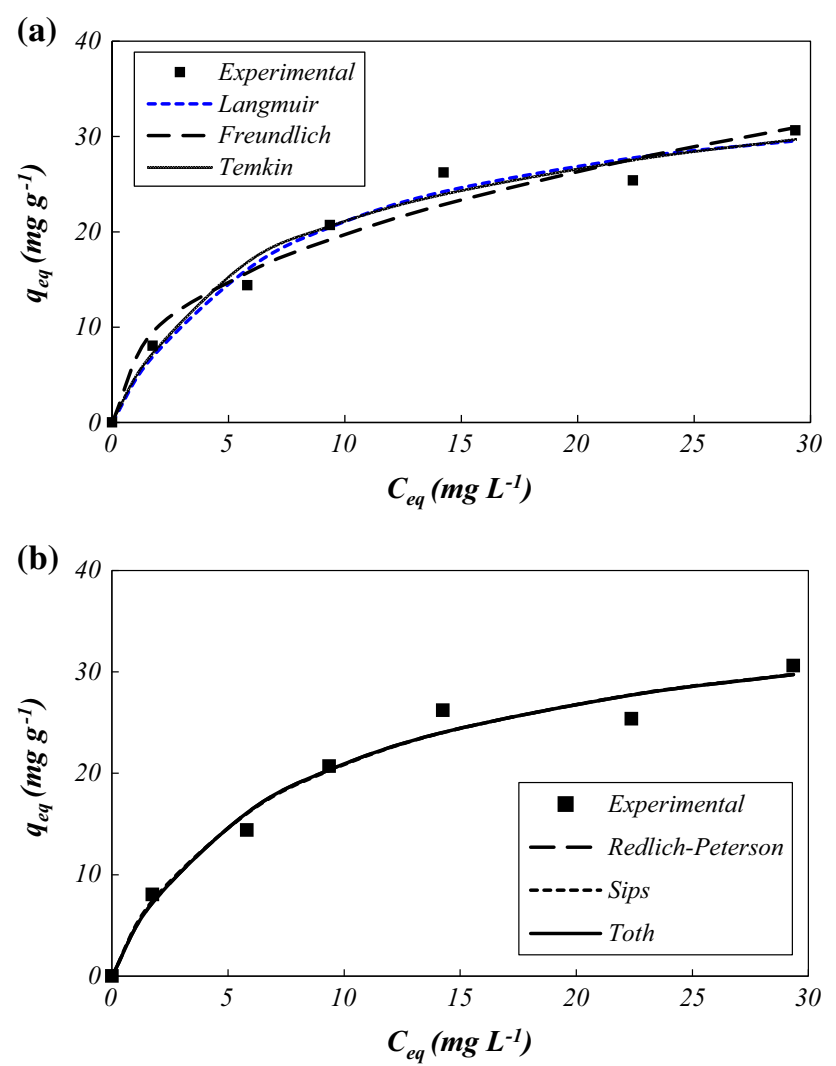

Fig. 6 Comparison of 2-parameters isotherm models (a) and 3-parameters isotherm models (b) for adsorption of $\mathrm{Cr}(\mathrm{VI})$ from the aqueous solutions onto $\mathrm{BCP}$ with experimental results $(\mathrm{BCP}=0.1 \mathrm{~g}$, $\mathrm{pH}=2, T=15 \pm 1{ }^{\circ} \mathrm{C}$ )

According to the results in Table 1, the $n$ value obtained from Freundlich model is above unity, indicate favorable adsorption conditions; however, the $R^{2}$ value for this isotherm is not close enough to 1 and shows that the Langmuir model provided a good fit to the experimental data when compared with the Freundlich model.

\section{Temkin isotherm}

Temkin isotherm is based on the assumption that due to the interaction between adsorbent-adsorbate, the heat of adsorption of all molecules in a certain layer decreases linearly with surface coverage (Samarghandi et al. 2009). This model can be expressed in the following equation:

$q_{e}=q_{m} \frac{R T}{\left(-\Delta H_{\mathrm{ad}}^{0}\right)} \ln \left(K_{T} C_{e}\right)$

where $T$ is absolute temperature $(K), R$ is universal gas constant $\left(\mathrm{J} \mathrm{mol}^{-1} \mathrm{~K}^{-1}\right), K_{T}$ is Temkin model constant $\left(\mathrm{L} \mathrm{mg}^{-1}\right)$ and $-\Delta H_{\mathrm{ad}}^{0}$ is the heat of adsorption $\left(\mathrm{J} \mathrm{mol}^{-1}\right)$. This model gives a satisfactory fit to the experimental data. For adsorption heat lower than $8 \mathrm{~kJ} \mathrm{~mol}^{-1}$, physisorption plays a significant role in the adsorption mechanism. The low value of the adsorption heat $\left(-\Delta H_{\mathrm{ad}}^{0}=4.77 \mathrm{~kJ} \mathrm{~mol}^{-1}\right)$ in this work, confirmed the physical adsorption of $\mathrm{Cr}(\mathrm{VI})$ by BCP.

\section{Redlich-Peterson isotherm}

The Redlich-Peterson equation is used as a comparison between Langmuir and Freundlich isotherms. This equation at the higher concentrations of adsorbate is converted to the Freundlich isotherms and because of its multifunctional property, it can be used in either homogenous or heterogeneous systems (Gimbert et al. 2008; Subramanyam and Das 2009). Redlich-Peterson isotherm can be described as follows:

$q_{e}=\frac{A C_{e}}{1+B C_{e}^{g}}$

where A and B are Redlich-Peterson model constants, and $\mathrm{g}$ is Redlich-Peterson model exponent. When $\mathrm{g}$ is equal to 1 , the Redlich-Peterson equation is converted to Langmuir

Table 2 Maximum adsorption capacity of BCP compared to the other adsorbents in the adsorption of $\mathrm{Cr}(\mathrm{VI})$

\begin{tabular}{|c|c|c|c|}
\hline Adsorbent & $\mathrm{pH}$ & $\mathrm{q}_{\mathrm{m}}\left(\mathrm{mg} \mathrm{g}^{-1}\right)$ & References \\
\hline FAC (Activated carbon derived from coconut fibers) & 2 & 21.75 & Mohan et al. (2005) \\
\hline SAC (Activated carbon derived from coconut shells) & 2 & 9.53 & Mohan et al. (2005) \\
\hline Activated carbon fabric cloth & 2 & 22.29 & Mohan et al. (2005) \\
\hline CSC (Coconut shell charcoal oxidized with nitric acid) & 4 & 10.88 & Babel and Kurniawan (2004) \\
\hline CAC (Commercial activated carbon oxidized with nitric acid) & 6 & 15.47 & Babel and Kurniawan (2004) \\
\hline Carbon slurry & 2 & 15.24 & Gupta et al. (2010) \\
\hline Granular activated carbon (Merck) & 6.5 & 3.9 & Rivera-Utrilla et al. (2003) \\
\hline Granular activated carbon (Merck) modified with the bacteria & 6.5 & 3.3 & Rivera-Utrilla et al. (2003) \\
\hline $\mathrm{BCP}$ & 2 & 37.28 & This work \\
\hline
\end{tabular}


and in the case of $g=0$, it is converted to Henrys' equation. According to the obtained value for $\mathrm{g}(0.93)$, it is obvious that the adsorption of $\mathrm{Cr}(\mathrm{VI})$ onto $\mathrm{BCP}$ mainly follows Langmuir isotherm.

\section{Sips isotherm}

In fact, the Sips isotherm is a composition of Langmuir and Freundlich isotherms which follows the Freundlich and Langmuir at the lower and higher adsorption concentrations, respectively. This isotherm predicts a single layer capacity of adsorption at the higher adsorption concentrations (Oubagaranadin and Murthy 2009; Subramanyam and Das 2009). The equation of Sips isotherm can be described using the following formula:

$q_{e}=\frac{q_{m}\left(K_{a} C_{e}\right)^{\alpha}}{1+\left(K_{a} C_{e}\right)^{\alpha}}$

where $K_{a}$ is Sips model constant $\left(\mathrm{L} \mathrm{mg}^{-1}\right)$, and $\alpha$ is Sips model exponent; this indicates the heterogeneity of system. According to the Table 1, the Sips isotherm fits adequately the experimental data. The $\alpha$ value is close to 1 and indicates that the adsorption process is mainly Langmuir form.

\section{Toth isotherm}

Toth isotherm model was derived from potential theory and is useful to describe the sorption process in heterogeneous systems. This model assumes an asymmetrical quasi-Gaussian energy distribution. According to this model, most sites have sorption energy less than the mean value of adsorption energy. This isotherm is converted to the Langmuir isotherm when $\beta$ is equal 1 (Allen et al. 2003; Oubagaranadin and Murthy 2009). Toth isotherm can be expressed using the following equation:

$q_{e}=\frac{q_{m} K_{T H} C_{e}}{\left[1+\left(K_{T H} C_{e}\right)^{\beta}\right]^{1 / \beta}}$

where $K_{\mathrm{Th}}$ is Toth model constant $\left(\mathrm{L} \mathrm{mg}^{-1}\right)$ and $\beta$ is Toth model exponent. According to the results in Table 1, the $\beta$ value obtained for our adsorption process is close to 1 ( $\beta=0.93$ ), so we can conclude that the adsorption of $\mathrm{Cr}(\mathrm{VI})$ onto BCP has good conformity with Langmuir isotherm.

\section{Adsorption kinetic studies}

Studying of adsorption kinetics is one of the most important investigations of adsorption process. Adsorption kinetic depends on the physical and chemical properties of adsorbent which influences the adsorption mechanism. Kinetic models are used to indicate the adsorption mechanism and final controlling steps (Ho and McKay 1999a). In order to understand the kinetics of $\mathrm{Cr}(\mathrm{VI})$ adsorption onto BCP as an adsorbent, pseudo-first-order and pseudosecond-order kinetic models are tested with the experimental data.

\section{Lagergren's pseudo-first-order kinetic model}

This model has been proposed by Lagergren and described as the below formula (Lagergren 1898):

$\mathrm{q}_{\mathrm{t}}=\mathrm{q}_{\mathrm{e}}\left(1-\mathrm{e}^{-\mathrm{k}_{1} \mathrm{t}}\right)$

where $q_{e}$ and $q_{t}$ are the amount of adsorbate adsorbed at equilibrium and at any time $\left(\mathrm{mg} \mathrm{g}^{-1}\right)$, respectively, and $\mathrm{k}_{1}$ is the first-order Lagergren model rate constant $\left(\min ^{-1}\right)$.
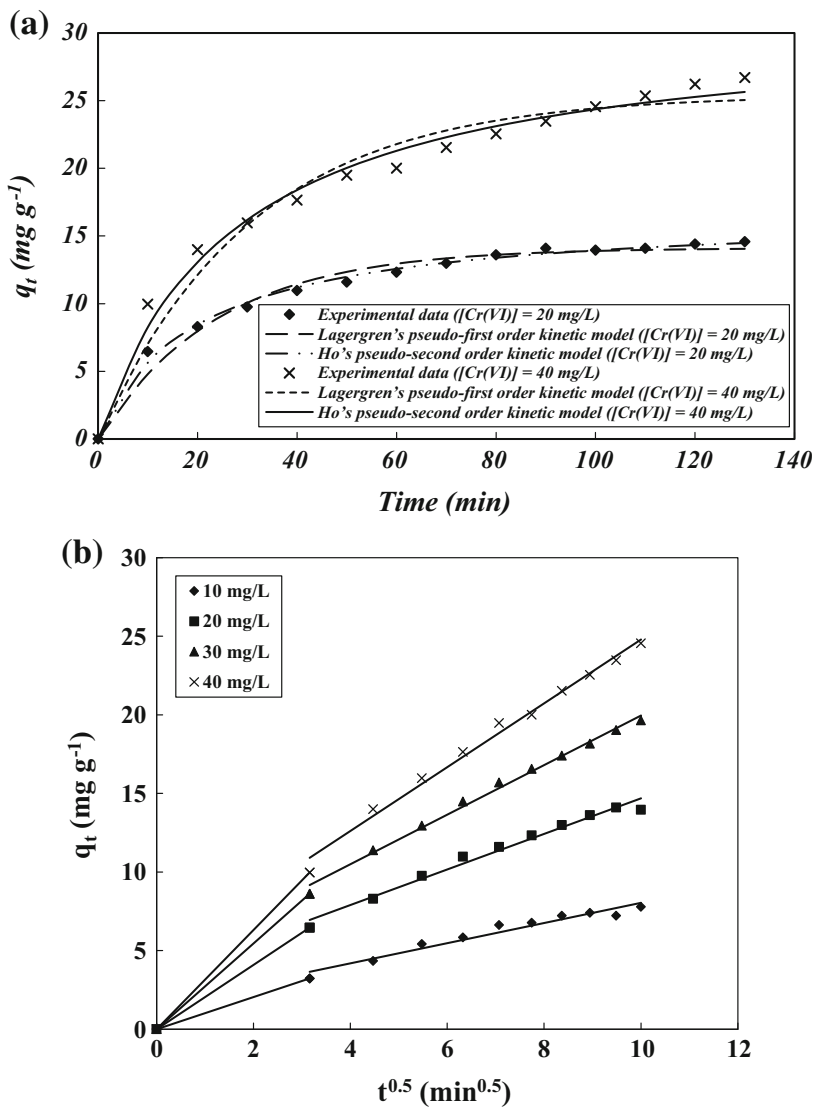

Fig. 7 Comparison of kinetic models with experimental results (a) and Weber-Morris kinetic model (b) for adsorption of $\mathrm{Cr}(\mathrm{VI})$ from aqueous solutions by $\mathrm{BCP} \quad(\mathrm{Ads}=0.1 \mathrm{~g}, \quad \mathrm{pH}=2$, $\left.T=15 \pm 1{ }^{\circ} \mathrm{C}\right)$ 


\section{Ho's pseudo-second-order kinetic model}

The Ho's pseudo-second-order kinetic model is described in the following way (Ho and McKay 1999b):

$q_{t}=\frac{q_{e}^{2} k_{2} t}{1+k_{2} q_{e} t}$

where $k_{2}$ is Ho pseudo-second-order kinetic model rate constant $\left(\mathrm{g} \mathrm{mg}^{-1} \mathrm{~min}^{-1}\right)$.

The values of $k_{1}, k_{2}$ and $q_{e}$ are given in Table 1 . The results in Table 1 and Fig. 7a show that $\mathrm{Cr}(\mathrm{VI})$ adsorption onto BCP has very good compliance with pseudo-secondorder kinetic model. The value of $\mathrm{R}^{2}$ is greater than 0.99 and also, $\mathrm{S}^{2}$ and Rmse are very close to zero. According to this model, two reactions occur, the first one is fast and reaches equilibrium quickly, and the second is slow that can continue for a long time (Behnajady et al. 2014; Mody et al. 2009).

\section{The mechanism of adsorption}

The intra-particle diffusion or Weber and Morris adsorption kinetic model was used to describe the mechanism of adsorption process (Weber and Morris 1963). This model is described as below:

$q=k_{i p} t^{0.5}+C_{i}$

where $k_{i p}$ is intra-particle diffusion kinetic model rate constant ( $\mathrm{mg} \mathrm{g}^{-1} \mathrm{~min}^{-0.5}$ ), and $\mathrm{C}_{\mathrm{i}}$ is the intercept of stage $\mathrm{i}$ which estimates the thickness of the boundary layer. According to this model, a linear plot indicates a rate controlled by intra-particle diffusion (Gad and El-Sayed 2009). Figure $7 \mathrm{~b}$ indicates that the adsorption process of the $\mathrm{Cr}(\mathrm{VI})$ onto BCP is comprised of two stages. At the first stage $(t<10 \mathrm{~min})$, a very fast adsorption is observed. The first stage of the plot indicated a fast adsorption of $\mathrm{Cr}(\mathrm{VI})$ onto the available external surface of adsorbent (boundary layer diffusion), whereas the second linear stage is due to intra-particle diffusion (Oubagaranadin and Murthy 2009). In this stage, the adsorption of $\mathrm{Cr}(\mathrm{VI})$ molecules occurs onto the active sites of the adsorbent internal surface. The intercept of the second stage lines provide an estimate of the thickness of the boundary layer. The larger intercept value indicates the greater boundary layer effect. The increase in $\mathrm{Cr}(\mathrm{VI})$ initial concentration causes an increase in the driving force and diffusion rate (Dogan et al. 2009). According to the results in Table 3, the values of intercept was found to increase with an increase in the initial $\mathrm{Cr}(\mathrm{VI})$ concentration, which indicated an increase in the thickness of the boundary layer and higher contribution of the surface adsorption in the rate-limiting
Table 3 Weber-Morris kinetic model parameters values

\begin{tabular}{llll}
\hline $\mathrm{Cr}(\mathrm{VI})$ initial concentration $\left(\mathrm{mg} \mathrm{L}^{-1}\right)$ & $\mathrm{K}_{\mathrm{ip}}$ & $\mathrm{C}_{\mathrm{i}}$ & $\mathrm{R}^{2}$ \\
\hline 10 & 0.642 & 1.621 & 0.953 \\
20 & 1.132 & 3.363 & 0.981 \\
30 & 1.579 & 4.177 & 0.993 \\
40 & 2.033 & 4.471 & 0.990 \\
\hline
\end{tabular}

step (Dogan et al. 2009). The slope of the second linear stage of the plot has been considered as the intra-particle diffusion rate constant $\left(k_{i p}\right)$. The multi-linearity plot indicates that the intra-particle diffusion is not merely the rate-controlling step for the whole adsorption process (Oubagaranadin and Murthy 2009).

\section{Conclusion}

In this work, the biochar particles obtained from the $\mathrm{OH}$ (BCP) was used as an alternative adsorbent for the removal of $\mathrm{Cr}(\mathrm{VI})$ from aqueous solution. The morphology and purity of BCP have been studied by SEM and EDX, respectively. The BET technique was used to evaluate the specific surface area of these particles and their pores and holes. As a result, the specific surface area is about $5.73 \mathrm{~m}^{2} \mathrm{~g}^{-1}$. The results confirm that the BCP is an efficient adsorbent for the removal of $\mathrm{Cr}(\mathrm{VI})$ from aqueous environments. The effect of various parameters such as the initial concentration of $\mathrm{Cr}(\mathrm{VI})$, the amount of adsorbent, and $\mathrm{pH}$ is investigated. The most proper $\mathrm{pH}$ value for this process was revealed as $\mathrm{pH}=1$. Various nonlinear isotherm models were evaluated, and the results proposed the Langmuir isotherm as the best and the most proper one for confirming the experimental data for this process. Studying nonlinear kinetic equations indicates that the removal adsorption process of $\mathrm{Cr}(\mathrm{VI})$ onto BCP follows Ho's pseudo-second-order kinetic model.

Acknowledgments The authors would like to thank the financial support of Tabriz Branch, Islamic Azad University.

\section{References}

Aliabadi M, Morshedzadeh K, Soheyli H (2006) Removal of hexavalent chromium from aqueous solution by lignocellulosic solid wastes. Int J Environ Sci Technol 3:321-325

Allen SJ, Gan Q, Matthews R, Johnson PA (2003) Comparison of optimised isotherm models for basic dye adsorption by kudzu. Bioresour Technol 88:143-152 
Allen SJ, Mckay G, Porter JF (2004) Adsorption isotherm models for basic dye adsorption by peat in single and binary component systems. J Colloid Interface Sci 280:322-333

Amuda OS, Giwa AA, Bello IA (2007) Removal of heavy metal from industrial wastewater using modified activated coconut shell carbon. Biochem Eng J 36:174-181

An Z, Zhang H, Wen Q, Chen Z, Du M (2014) Desalination combined with hexavalent chromium reduction in a microbial desalination cell. Desalination 354:181-188

Ayoama M, Sugiyama T, Doi S, Cho NS, Kim HE (1999) Removal of hexavalent chromium from dilute aqueous solution by coniferous leaves. Holzforschung 53:365-368

Bailey SE, Olin TJ, Bricka RM, Adrian DD (1999) A review of potentially low-cost sorbents for heavy metals. Water Res 33:2469-2479

Behnajady MA, Bimeghdar S (2014) Synthesis of mesoporous NiO nanoparticles and their application in the adsorption of $\mathrm{Cr}(\mathrm{VI})$. Chem Eng J 239:105-113

Behnajady MA, Mansoriieh N, Modirshahla N, Shokri M (2012) Influence of operational parameters and kinetics analysis on the photocatalytic reduction of $\mathrm{Cr}(\mathrm{VI})$ by immobilized $\mathrm{ZnO}$. Environ Technol 33:265-271

Behnajady MA, Yavari SH, Modirshahla N (2014) Investigation adsorption capacity of $\mathrm{TiO}_{2}-\mathrm{P} 25$ nanoparticles in the removal of a mono-azo dye from aqueous solution: a comprehensive isotherm analysis. Chem Ind Chem Eng Q 20:97-107

Bhowal A, Bhattacharyya G, Inturu B, Datta S (2012) Continuous removal of hexavalent chromium by emulsion liquid membrane in a modified spray column. Sep Purif Technol 99:69-76

Chowdhury S, Mishra R, Saha P, Kushwaha P (2011) Adsorption thermodynamics, kinetics and isosteric heat of adsorption of malachite green onto chemically modified rice husk. Desalination 265:159-168

Chun L, Hongzhang C, Zuoho L (2004) Adsorptive removal of Cr(VI) by $\mathrm{Fe}$-modified steam exploded wheat straw. Proc Biochem 39:541-545

Das N, Vinodhini V (2010) Packed bed column studies on Cr(VI) removal from tannery wastewater by neem sawdust. Desalination 264:9-14

Dogan M, Abak H, Alkan M (2009) Adsorption of methylene blue onto hazelnut shell: kinetics, mechanism and activation parameters. J Hazard Mater 164:172-181

Gad HMH, El-Sayed AA (2009) Activated carbon from agricultural by-products for the removal of Rhodamine-B from aqueous solution. J Hazard Mater 168:1070-1081

Garg UK, Kaur MP, Garg VK, Sud D (2007) Removal of hexavalent chromium from aqueous solution by agricultural waste biomass. J Hazard Mater 140:60-68

Gimbert F, Morin-Crini N, Renault F, Badot PM, Crini G (2008) Adsorption isotherm models for dye removal by cationized starch-based material in a single component system: error analysis. J Hazard Mater 157:34-46

Gode F, Atalay ED, Pehlivan E (2008) Removal of Cr(VI) from aqueous solutions using modified red pine sawdust. J Hazard Mater 152:1201-1207

Gupta S, Babu BV (2009) Removal of toxic metal Cr(VI) from aqueous solutions using sawdust as adsorbent: equilibrium, kinetics and regeneration studies. Chem Eng J 150:352-365

Ho YS, McKay G (1999a) Comparative sorption kinetic studies of dyes and aromatic compounds onto fly ash. J Environ Sci Health A 34:1179-1204
Ho YS, McKay G (1999b) Pseudo-second order model for sorption pr ocesses. Process Biochem 34:451-465

Ho YS, Porter JF, Mckay G (2001) Equilibrium isotherm studies for the sorption of divalent metal ions onto peat: copper, nickel and lead single component systems. Water Air Soil Pollut 141:1-33

Hu J, Chen G, Lo IMC (2005) Removal and recovery of Cr(VI) from wastewater by maghemite nanoparticles. Water Res 39:4528-4536

Kadirvelu K, Thamaraiselvi K, Namasivayam C (2001) Adsorption of nickel(II) from aqueous solution onto activated carbon prepared from coirpith. Sep Purif Technol 24:497-505

Kotas J, Stasicka Z (2000) Chromium occurrence in the environment and methods of its speciation. Environ Pollut 107:263-283

Kundu S, Gupta AK (2006) Arsenic adsorption onto iron oxide-coated cement (IOCC): regression analysis of equilibrium data with several isotherm models and their optimization. Chem Eng J 122:93-106

Lagergren S (1898) Zur theorie der sogenannten adsorption geloster stoffe. K seven Vetenskapsakad Handl 24:1-39

Mahmood T, Saddique MT, Naeem A, Westerhoff P, Mustafa S, Alum A (2011) Comparison of different methods for the point of zero charge determination of $\mathrm{NiO}$. Ind Eng Chem Res 17:10017-10023

Malkoc E, Nuhoglu Y (2006) Fixed bed studies for the sorption of chromium(VI) onto tea factory waste. Chem Eng Sci 61:4363-4372

Mane VS, Vijay- Babu PV (2011) Studies on the adsorption of Brilliant Green dye from aqueous solution onto low-cost $\mathrm{NaOH}$ treated saw dust. Desalination 273:321-329

Marshall WE, Wartelle LH (2004) An anion exchange resin from soybean hulls. J Chem Technol Biotechnol 79:1286

Mody K, Khambhaty Y, Basha Sh, Jha B (2009) Kinetics, equilibrium and thermodynamic studies on biosorption of hexavalent chromium by dead fungal biomass of marine Aspergillus niger. Chem Eng J 145:489-495

Mohapatra P, Samantaray SK, Parida K (2005) Photocatalytic reduction of hexavalent chromium in aqueous solution over sulphate modified titania. J Photochem Photobiol A 170:189-194

Moreno-Pirajan JC, Fonseca-Correa R, Giraldo L (2013) Trivalent chromium removal from aqueous solution with physically and chemically modified corncob waste. J Anal Appl Pyrolysis 101:132-141

Oubagaranadin JUK, Murthy ZVP (2009) Modeling of adsorption of chromium (VI) on activated carbons derived from corn (Zea mays) cob. Chem Prod Process Model 4 Article 32, doi: 10.2202/ 1934-2659.1377

Rasoulifard MH, Esfahlani FH, Mehrizadeh H, Sehati N (2010) Removal of C.I. basic yellow 2 from aqueous solution by lowcost adsorbent: hardened paste of Portland cement. Environ Technol 31:277-284

Rivera-Utrilla J, Bautista-Toledo I, Ferro-García MA, MorenoCastilla C (2003) Bioadsorption of $\mathrm{Pb}(\mathrm{II}), \mathrm{Cd}(\mathrm{II})$, and $\mathrm{Cr}(\mathrm{VI})$ on activated carbon from aqueous solutions. Carbon 41:323-330

Rouquerol J, Rouquerol F, Llewellyn P, Maurin G, Sing KSW (2013) Adsorption by powders and porous solids, principles, methodology and applications, 2nd edn. Academic Press, Cambridge

Samarghandi MR, Hadi M, Moayedi S, Barjasteh Askari F (2009) Two-parameter isotherms of methyl orange sorption by pinecone derived activated carbon. Iran $\mathbf{J}$ Environ Health Sci Eng 6:285-294 
Subramanyam B, Das A (2009) Study of the adsorption of phenol by two soils based on kinetic and isotherm modeling analyses. Desalination 249:914-921

Venkateswaran P, Palanivelu K (2004) Solvent extraction of hexavalent chromium with tetrabutyl ammonium bromide from aqueous solution. Sep Purif Technol 40:279-284
Weber WJ, Morris JC (1963) Kinetics of adsorption on carbon from solution. J Sanit Eng Div Am Soc Civ Eng 89:31-60

Zongo I, Leclerc JP, Amadou-Maiga H, Wethe J, Lapicque F (2009) Removal of hexavalent chromium from industrial wastewater by electrocoagulation: a comprehensive comparison of aluminium and iron electrodes. Sep Purif Technol 66:159-166 